\title{
High-fat Diet Aggravates Islet Beta-cell Toxicity in Mice Treated with Clozapine
}

\author{
Chung-Huei Huang, MD; Shin-Huei Fu'; Samuel Hsu, MD; Yu-Yao Huang, MD, PhD; \\ Szu-Tah Chen, MD, PhD; Brend Ray-Sea Hsu, MD, PhD
}

Background: Clozapine, an atypical antipsychotic drug, induces derangements in glucose homeostasis in certain patients. This study investigated the mechanisms of clozapine-induced beta-cell toxicity.

Methods: Fifty-two healthy C57BL/6 male mice were randomized into 4 groups to study the effects of clozapine (group C, D) and a high-fat diet (group B, D). Three mice from each group were randomly selected to determine the amount of food intake on days 8-10, and their pancreases were removed for histological examination on day 11. The remaining 10 mice in each group were sacrificed at the 8th week to measure pancreatic insulin content (PIC).

Results: $\quad$ Mice given clozapine for 8 weeks demonstrated trends of lower PIC. The histological examination of the pancreases retrieved on day 11 already revealed apoptotic changes and suppression of cell proliferation. Although mice fed high-fat chow gained weight, mice given both clozapine and a highfat diet showed less weight gain and more severe histological deterioration, and had the lowest PIC levels of the 4 groups.

Conclusion: Pancreatic beta-cell apoptosis, suppression of cell proliferation, and trends of reduction in pancreatic insulin content were observed in mice taking clozapine. The findings of clozapine induced beta-cell toxicity were further aggravated when mice were concomitantly fed a high-fat diet.

(Chang Gung Med J 2012;35:318-22)

Key words: beta-cell toxicity, clozapine, high-fat diet, apoptosis, Ki67, pancreatic insulin content

$\mathrm{T}$ he administration of second-generation (atypical) antipsychotic drugs is reported to be associated with hyperglycemia. ${ }^{(1-4)}$ The mechanisms of this clinical observation are still not fully elucidated. Hepatic insulin resistance has been reported in rat studies with a dose-dependent pattern. ${ }^{(2,5)}$ Smith and his colleagues found that atypical antipsychotic drugs induced hyperglycemia by acutely increasing glucagon secretion and hepatic glucose output in a rat model. ${ }^{(6)}$ Reports of peripheral insulin resistance induced by atypical antipsychotic drugs were conflicted. No peripheral insulin resistance was demonstrated in dogs treated with risperidone or olanzapine for 4-6 weeks. ${ }^{(7)}$ A study using clamp techniques also revealed no peripheral insulin resistance in rats. ${ }^{(5)}$ Chintoh and his colleagues, however, reported peripheral insulin resistance occurred immediately following one dose injection of atypical antipsychotic medications. ${ }^{(2)}$ They also reported a transient impairment of insulin secretion, which was

From the Division of Endocrinology and Metabolism, Department of Internal Medicine, Chang Gung Memorial Hospital at Linkou, Chang Gung University College of Medicine, Taoyuan, Taiwan; 'Taiwan International Graduate Program, Graduate Institute of Life Science, National Defence Medical Center and Academia Sinica, Taiwan.

Received: Aug. 17, 2011; Accepted: Jan. 30, 2012

Correspondence to: Dr. Brend Ray-Sea Hsu, Division of Endocrinology and Metabolism, Department of Internal Medicine, Chang Gung Memorial Hospital at Linkou. 5, Fusing St., Gueishan Township, Taoyuan County 333, Taiwan (R.O.C.)

Tel: 886-3-3281200 ext. 8823; Fax: 886-3-328-8257; E-mail: bh0658@cgmh.org.tw 
reversible after the mice recovered from the acute dose of medication. ${ }^{(2)}$

Not all schizophrenic patients taking clozapine develop overt diabetes. ${ }^{(8,9)}$ Weight gain and metabolic syndrome are commonly observed in patients treated for schizophrenia. ${ }^{(1,9)}$ We were interested in studying the beta-cell damage since acute decreased insulin secretion was reported by Chintoh et al. ${ }^{(2)}$ Therefore we designed this study to examine beta-cell histology and insulin content in mice treated with clozapine for 8 weeks. Also, we introduced a high-fat diet model in addition to clozapine treatment to test further beta-cell changes while adaptive compensation of beta-cells takes place. ${ }^{(10,11)}$

\section{METHODS}

Male C57BL/6 mice (8-12-week old) were obtained from a local breeder and 3 to 5 mice were housed in each cage and fed pelleted food and tap water ad libitum. Mice were fed either regular chow (5001 LabDiet, $3.17 \mathrm{Kcal} / \mathrm{g}, 12 \% \mathrm{kcal}$ from fat) or a high-fat diet (TestDiet, $5.17 \mathrm{Kcal} / \mathrm{g}, 60 \% \mathrm{kcal}$ from fat), both obtained from Purina (Richmond, IN, U.S.A.), for 8 weeks. The animals were maintained on a lighting cycle of $12 \mathrm{~h}$ light and $12 \mathrm{~h}$ darkness.

Fifty-two healthy C57BL/6 male mice were randomly separated into 4 groups. Mice in groups $\mathrm{C}$ and D were orally administrated $13.5 \mathrm{mg} / \mathrm{kg}$ body weight of clozapine six days a week between 8 AM to 9 AM. Distilled water was given to mice in groups A and $\mathrm{B}$ as control groups. Mice in groups $\mathrm{A}$ and $\mathrm{C}$ were fed a regular diet while mice in groups $\mathrm{B}$ and $\mathrm{D}$ were fed a high-fat diet.

The non-fasting blood glucose was measured at $8 \mathrm{AM}$ daily and body weight was measured twice a week. The change of body weight $(\Delta \mathrm{BW})$ was calculated as the difference in the average body weight between the first and eighth weeks.

Three mice from each group were randomly selected to be housed in metabolic cages between the $7^{\text {th }}$ to $11^{\text {th }}$ days to measure diet intake. Then, the mice were sacrificed for histological examination of the pancreases on day 11. The apoptotic and proliferative nuclei in the islets of paraffin-embedded pancreatic sections were detected using the TUNEL Apoptosis Detection Kit bought from GenScrip (Piscataway, NJ, U.S.A.) and an immunohistochemical examination was done using anti-Ki67 antibody (ab15580) obtained from Abcam Inc. (Cambridge, MA, U.S.A.).

The remaining 10 mice in each group were sacrificed at the end of 8 weeks and the pancreases were removed to measure pancreatic insulin content (PIC) using an acid-ethanol extraction and insulin kit (\# RI-13k) bought from LINCO Research, Inc. (St. Charles, MO, U.S.A.). The animals were treated humanely in accordance with the laboratory animal guidelines of Chang Gung Memorial Hospital. Since normality was not achieved, the results were given as median values [minimum; maximum], and the nonparametric Wilcoxon signed-rank test, MannWhitney test, and Kruskal-Wallis test were performed for comparisons as appropriate. A value of $p$ $<0.05$ was considered significant.

\section{RESULTS}

The dietary intake measured between day 8 to day 10 was significantly decreased in mice fed a high-fat diet. Nevertheless, the daily caloric intake did not differ among 4 groups (Table 1). Mildly elevated blood glucose levels were observed only in mice fed high-fat chow (group B) on day 56 (Table 2 ). Among the 4 groups, group B (high-fat chow) had a significant weight gain while group C (clozapine) had a weight loss at the $8^{\text {th }}$ week. The mice fed high-fat chow and treated by clozapine simultaneously (Group D) had a significantly lower weight than those fed only a high-fat diet (Group B), indicating clozapine attenuated the weight gain effect that was induced by the high-fat diet.

Pancreatic histology showed higher TUNEL apoptosis and less anti-Ki67 detection on day 11 in the beta-cells of mice given clozapine (group C) (Table 1), compared with the control (group A) and mice fed high-fat chow (group B). The results indicated more apoptosis and less pancreatic proliferation developed in mice treated with clozapine. These findings of beta-cell toxicity caused by clozapine administration were further aggravated when mice were simultaneously fed a high-fat diet (group D).

At the $8^{\text {th }}$ week, trends of a reduced PIC were observed in group C while an increased PIC was observed in group B, although this did not reach significance in our study (Table 2). The PIC in mice simultaneously treated with clozapine and a high-fat diet (group D) showed the lowest level of all 4 
Table 1. Effects of 10-day Clozapine and High-fat Diet on Mouse Appetite and Apoptosis and Proliferation of Pancreatic Beta Cells

\begin{tabular}{|c|c|c|c|c|c|c|c|}
\hline $\mathrm{Gr}$ & $\mathrm{n}$ & Clozapine & HF diet & $\begin{array}{l}\text { Daily intake } \\
(\mathrm{g} / 100 \mathrm{~g} \mathrm{BW})\end{array}$ & $\begin{array}{c}\text { Daily calories } \\
\text { (Kcal/100 g BW) }\end{array}$ & Apoptosis & Ki67 positivity \\
\hline A & 3 & - & - & $14.8[13.6 ; 15.0]$ & $46.9[43.2 ; 47.6]$ & + & +++ \\
\hline B & 3 & - & + & $6.6[6.6 ; 8.5]$ & $33.9[33.8 ; 45.8]$ & + & +++ \\
\hline $\mathrm{C}$ & 3 & + & - & $14.5[12.4 ; 15.0]$ & $46.0[39.2 ; 47.7]$ & ++ & + \\
\hline D & 3 & + & + & $6.9[6.5 ; 7.2]$ & $37.0[33.3 ; 37.3]$ & +++ & $+1-$ \\
\hline
\end{tabular}

Abbreviations: HF: high fat; BW: body weight. The numeric data for daily intake and calories are given as median values [minimum; maximum]. No statistical differences were observed in daily intake and calories among the four groups (Kruskal-Wallis test).

Table 2. Effects of Clozapine and High-fat Diet on Random Non-fasting Blood Glucose, Body Weight Changes, and Pancreatic Insulin Content

\begin{tabular}{ccccccccc}
\hline Gr & $\mathrm{n}$ & Clozapine & HF diet & D0 BG & D28 BG & D56 BG & $\Delta \mathrm{BW}(\mathrm{g})$ & PIC $(\mu \mathrm{g})$ \\
\hline $\mathrm{A}$ & 10 & - & - & $148[136 ; 190]$ & $123[92 ; 148]$ & $152[142 ; 160]$ & $3.5[2.1 ; 5.1]^{\mathrm{a}, \mathrm{b}}$ & $3.4[1.7 ; 4.7]^{\mathrm{f}}$ \\
$\mathrm{B}$ & 10 & - & + & $151[98 ; 177]$ & $150[118 ; 195]^{*}$ & $180[153 ; 203]^{*}, \dagger$ & $10.7[5.5 ; 20.7]^{\mathrm{a}, \mathrm{c}, \mathrm{d}}$ & $4.0[1.7 ; 4.7]_{\mathrm{g}, \mathrm{h}}$ \\
$\mathrm{C}$ & 10 & + & - & $143[101 ; 177]$ & $115[85 ; 125]$ & $120[97 ; 157]$ & $1.4[0.3 ; 2.2]^{\mathrm{b}, \mathrm{c}, \mathrm{e}}$ & $2.3[1.6 ; 3.3]_{\mathrm{g}}$ \\
$\mathrm{D}$ & 10 & + & + & $151[89 ; 179]$ & $107[68 ; 150]$ & $118[98 ; 136]$ & $6.4[1.3 ; 9.1]_{\mathrm{d}, \mathrm{e}}$ & $1.9[0.6 ; 2.5]^{\mathrm{f}, \mathrm{h}}$ \\
\hline
\end{tabular}

Abbreviations: HF: high fat; D: day; BG: blood glucose; $\triangle \mathrm{BW}$ : change in body weight; PIC: pancreatic insulin content. The BG level is expressed in $\mathrm{mg} / \mathrm{dL}$. The change of body weight $(\Delta \mathrm{BW})$ was expressed as the difference of body weight between the eighth and first weeks. The PIC was measured on day 56.

The results are given as median values [minimum; maximum]. *: $p<0.005$ when the indicated BG level was compared with that of other groups on the same day using the Kruskal-Wallis test; $\uparrow: p<0.05$ when the indicated BG level was compared with that of day 0 in the same group using the Wilcoxon Signed Rank test; $\mathrm{a}, \mathrm{b}, \mathrm{c}, \mathrm{e}, \mathrm{g}, \mathrm{h}: p<0.005$, d: $p<0.01$, f: $p<0.05$ when the indicated two data were analyzed using the Mann-Whitney test.

groups, and was $55.8 \%$ of the PIC found in group A $(1.9 \mu \mathrm{g}$ and $3.4 \mu \mathrm{g}$ as median values in group D and group A, respectively in Table 2). A statistical difference was reached when the PIC of mice in group D were compared to those in the control (group A) and high-fat diet (group B) groups. The PIC findings of were compatible with the findings of beta-cell histology (Table 1) which showed trends of beta-cell toxicity with clozapine (group C), and further impaired beta-cells in mice taking clozapine and high-fat chow simultaneously.

\section{DISCUSSION}

In this study, we found that clozapine-induced apoptosis of mouse pancreatic islet cells occurred as early as 10 days after drug administration. Moreover, a high-fat diet aggravated apoptosis and inhibited proliferation of islet cells in mice taking clozapine. The long-term toxic effects of the combination of clozapine and a high-fat diet were reflected in the significant reduction in the PIC in mice given a highfat diet and clozapine for 8 weeks.

The mechanism of action of clozapine-induced pancreatic toxicity is not yet clear. Chintoh et al. reported that deterioration of plasma insulin secretion can be observed immediately following a single dose of clozapine injection. ${ }^{(2)}$ Subsequently, they found beta-cell function can be restored. ${ }^{(2)}$ Our study observed significant damage to beta-cells when mice were treated with clozapine for 10 days. Although no statistical difference was reached, a trend of PIC reduction was demonstrated in group $\mathrm{C}$ following 8 weeks of treatment, implicating beta-cell toxicity from clozapine. It has been reported that a longer duration of atypical antipsychotics is associated with a higher risk of diabetes. ${ }^{(14)}$ The trend of PIC loss could be anticipated after further chronic treatment with clozapine. The beta-cell toxicity we observed may correlate with clinical reports of diabetic ketoacidosis in patients taking atypical antipsychotics. ${ }^{(4,12,13)}$

Feeding high-fat chow resulted in weight gain and a trend of PIC increment in mice, suggesting beta-cell hyperplasia in mice given a high-fat diet. ${ }^{(11)}$ When mice received both clozapine treatment and a high-fat diet, the PIC was much lower when compared with control mice (group A) or mice fed a 
high-fat diet without clozapine (group B). It is possible that the compensating islet beta-cells are more vulnerable to clozapine administration. However, further research is required to elucidate the underlying mechanism. Our findings in mice might relate to the clinical study recently reported by Argo et al. ${ }^{(14)}$ In 202 patients with schizophrenia, they found the waist-to-hip ratio and body mass index were factors most strongly associated with an increased risk of diabetes. ${ }^{(14)}$

Although we reported beta-cell damage in our experiment, the PIC in group D was $55.8 \%$ of that in group A. A greater than $80-90 \%$ reduction of betacell mass is required for development of overt insulin-dependent diabetes in humans, pigs, and rats. ${ }^{(15,16)}$ This might explain why the blood glucose remained euglycemic in those drug- treated mice.

Although a decreased daily intake was observed, body weight gain was still noted in our study in the high-fat chow groups. A further explanation of metabolic efficiency may be needed. A large study of mice with a high-fat diet model indicated that weight gain in mice given a high-fat diet is not fully explained by energy intake but is also correlated with a reduction in the metabolic rate. ${ }^{(11)}$ In addition, since the administration of clozapine did not change the amount of chow and the daily calorie intake, the explanation for the lower increment of body weight in mice taking clozapine is not clear.

In conclusion, we found that feeding a high-fat diet aggravates clozapine-induced toxicity in islet beta-cells of healthy adult mice. High-fat intake should be carefully controlled in patients taking clozapine for treatment of schizophrenia.

\section{Acknowledgements}

This work was supported by grant number NSC98-2314-B-182A-016-MY3 from the National Science Council.

\section{REFERENCES}

1. Newcomer JW. Second-generation (atypical) antipsychotics and metabolic effects: a comprehensive literature review. CNS Drugs 2005;19 Suppl 1:1-93.

2. Chintoh AF, Mann SW, Lam L, Giacca A, Fletcher P, Nobrega J, Remington G. Insulin resistance and secretion in vivo: effects of different antipsychotics in an animal model. Schizophr Res 2009;108:127-33.

3. Cooper GD, Harrold JA, Halford JC, Goudie AJ. Chronic clozapine treatment in female rats does not induce weight gain or metabolic abnormalities but enhances adiposity: implications for animal models of antipsychotic-induced weight gain. Prog Neuropsychopharmacol Biol Psychiatry 2008;32:428-36.

4. Kamran A, Doraiswamy PM, Jane JL, Hammett EB, Dunn L. Severe hyperglycemia associated with high doses of clozapine. Am J Psychiatry 1994;151:1395.

5. Houseknecht KL, Robertson AS, Zavadoski W, Gibbs EM, Johnson DE, Rollema H. Acute effects of atypical antipsychotics on whole-body insulin resistance in rats: implications for adverse metabolic effects. Neuropsychopharmacology 2007;32:289-97.

6. Smith GC, Chaussade C, Vickers M, Jensen J, Shepherd PR. Atypical antipsychotic drugs induce derangements in glucose homeostasis by acutely increasing glucagon secretion and hepatic glucose output in the rat. Diabetologia 2008;51:2309-17.

7. Ader M, Kim SP, Catalano KJ, Ionut V, Hucking K, Richey JM, Kabir M, Bergman RN. Metabolic dysregulation with atypical antipsychotics occurs in the absence of underlying disease: a placebo-controlled study of olanzapine and risperidone in dogs. Diabetes 2005;54:862-71.

8. Bai YM, Chen TT, Yang WS, Chi YC, Lin CC, Liou YJ, Wang YC, Su TP, Chou P, Chen JY. Association of adiponectin and metabolic syndrome among patients taking atypical antipsychotics for schizophrenia: a cohort study. Schizophr Res 2009;111:1-8.

9. Pramyothin P, Khaodhiar L. Metabolic syndrome with the atypical antipsychotics. Curr Opin Endocrinol Diabetes Obes 2010;17:460-6.

10. Sandu O, Song K, Cai W, Zheng F, Uribarri J, Vlassara H. Insulin resistance and type 2 diabetes in high-fat-fed mice are linked to high glycotoxin intake. Diabetes 2005;54: 2314-9.

11. Winzell MS, Ahren B. The high-fat diet-fed mouse: a model for studying mechanisms and treatment of impaired glucose tolerance and type 2 diabetes. Diabetes 2004;53 Suppl 3:S215-9.

12. Ramankutty G. Olanzapine-induced destabilization of diabetes in the absence of weight gain. Acta Psychiatr Scand 2002;105:235-6; discussion 36-7.

13. Ramaswamy K, Kozma CM, Nasrallah H. Risk of diabetic ketoacidosis after exposure to risperidone or olanzapine. Drug Saf 2007;30:589-99.

14. Argo T, Carnahan R, Barnett M, Holman TL, Perry PJ. Diabetes prevalence estimates in schizophrenia and risk factor assessment. Ann Clin Psychiatry 2011;23:117-24.

15. Bonner-Weir S, Trent DF, Weir GC. Partial pancreatectomy in the rat and subsequent defect in glucose-induced insulin release. J Clin Invest 1983;71:1544-53.

16. Kloppel G, Lohr M, Habich K, Oberholzer M, Heitz PU. Islet pathology and the pathogenesis of type 1 and type 2 diabetes mellitus revisited. Surv Synth Pathol Res 1985;4:110-25. 


\title{
高脂肪食物加重 clozapine 對胰島 $\beta$ 細胞的毒害性
}

\author{
黄瓊慧 傅馨慧1 許嵉元 黄禹堯 陳思達 許瑞旭
}

背 景: clozapine 是一種非典型抗精神病藥物, 臨床上使用此類藥物易造成葡萄醣代謝平衡 失調。本篇研究探討 clozapine 對胰岛 $\beta$ 細胞的毒害及與高脂肪飲食的相關性。

方 法: 隨機將 52 隻 C57BL/6 雄性小鼠分成四組。A、B 組揋食蒸餾水, C、D 組揋食 clozapine。此外 A、C 組揋食一般飼料, B、D 組則給予高脂肪飼料。分別記錄小鼠的食 量、體重及非空腹血糖。第 11 天每組隨機取三隻小鼠對其胰臟作組織檢查, 研究胰 島細胞调亡 (apoptosis) 及進行抗 Ki67 抗體免疫染色。其餘實驗鼠則在第 8 週檢驗其 胰藏中胰岛素含量。

結 果: 本實驗顯示 clozapine 揋食會造成小鼠體重減輕、胰岛細胞调亡及胰岛細胞增生減 少，長期使用造成胰臟胰岛素含量降低。高脂肪餵食會使實驗鼠體重增加、血糖上 升及胰藏中胰島素含量增加。然而, 在 clozapine 治療組同時揋食高脂肪卻會加重胰 島細胞调亡，顯著減少胰藏中胰岛素含量。

結 論： 我們發現 clozapine 對小鼠胰島 $\beta$ 細胞具明顯毒害性。而高脂肪食物會惡化 clozapine 的胰岛破壞。建議臨床上病人使用此類藥物治療精神疾病須避免高脂肪飲食。

(長庚醫誌 2012;35:318-22)

關鍵詞：胰岛細胞毒害性, clozapine, 高脂肪飲食, 自體调亡, Ki67, 胰臟胰岛素含量

長庚醫療財團法人林口長庚紀念醫院 內科部 內分泌新陳代謝科; 長庚大學 醫學院; '中央研究院 國際研究生分子細胞 生物學程暨國防醫學院 生命科學研究所

受文日期：民國100年8月17日；接受刊載：民國101年1月30日

通訊作者: 許瑞旭醫師, 長庚醫療財團法人林口長庚紀念醫院 內分泌新陳代謝科。桃園縣333龜山鄉復興街5號。

Tel: (03)3281200轉8823; Fax: (03)3288257; E-mail: bh0658@cgmh.org.tw 